\title{
Rangelands Index for 2009
}

A

A Challenge for All: Successfully

Transferring Wealth and

Management on Family Ranches, 31(2):2

An interview with a fence post, 31(5):41

An interview with G. Robert (Bob)

Welling, 31(3):41

An interview with Mountain Death

Camus, 31(1):50

Are Changes in Species Composition on Central North Dakota

Rangelands Due to Non-Use

Management?, 31(6):16

Aten, Melany, 31(2):26

B

Bean, Travis M., 31(3):6

Behavioral Factors in Rotational

Grazing Systems, 31(5):20

Benefits of Managed Grazing:

A Manager's Perspective, 31(5):11

Bleich, Vernon C., 31(5):15

Block, William M., 31(5):15

Book Reviews, 31(2):48, 31(3):52, 31(4):27, 31(6):36

Breeding Bird Selection of Restored and Native Wooded Draws in North Dakota, 31(6):9

Brown, Joel, 31(5):3, 31(5):37

Browsing the Literature, 31(1):54, 31(2):42, 31(3):46, 31(4):21, 31(5):45, 31(6):30

Brunson, Mark W., 31(5):20

Budd, Bob, 31(5):11

Building a Vision that Drives Success and Transition in a Family Ranch

Business, 31(2):8

Burritt, Elizabeth A., 31(5):20

C

Caballero, Armando, 31(2):8

Casady, Grant M., 31(3):6

Chambers, Jeanne C., 31(3):14

Cibils, Andres, 31(6):3

Clambey, Gary, 31(6):16

Clemensen, Andrea, 31(1):45

Clements, Charlie D., 31(3):30

Coates-Markle, Linda, 31(3):2

Cold Desert Fire and Invasive

Species Management: Resources,
Strategies, Tactics, and Response, 31(3):14

Colorado Landscapes Past and

Future: A Photographer's

Perspective (An interview with John

Fielder), 31(4):5

Cook, Daniel, 31(1):10, 31(1):16, 31(1):22, 31(6):3

Creamer, Rebecca, 31(6):3

Crooked Calf Syndrome: Managing Lupines on Rangelands of the Channel Scablands of East-Central Washington State, 31(1):10

D

Davis, T. Zane, 31(1):28, 31(1):35, 31(1):38

DeKeyser, Shawn, 31(6):16

Devoe, Nora, 31(3):21

Díaz-Solís, Heriberto, 31(5):31

Dunn, Barry H., 31(2):2

E

Early Living on the High Plains-

Problems and Challenges (An interview with Elliott West), 31(4):8

Editor's Note, 31(6):1

Effective Management of Invasive

Plants, 31(3):21

Encinias, Manny, 31(6):3

Environmental History of the High

Plains (An interview with Mark

Fiege), 31(4):14

Essays of a Peripheral Mind, 31(2):36, 31(5):39

Estate Planning: A Complex Process of Critical Importance to Ranches, 31(2):14

$\mathbf{F}$

Fire and Invasive Species

Management in Hot Deserts:

Resources, Strategies, Tactics, and

Response, 31(3):6

Florence, Scott, 31(3):21

Frasier, Gary, 31(4):2, 31(4):5, $31(4): 8,31(4): 10,31(4): 14,31(4): 18$

Frieberg, Becky, 31(3):36

Frisina, Michael R., 31(5):15

Fuels Management at the Landscape Scale, 31(3):25
G

Gardner, Dale R., 31(1):22, 31(1):35, 31(1):45

Gardner, Kevin, 31(6):3

Gay, Clive C., 31(1):10

Gilgert, Wendell, 31(3):25

Goergen, Erin, 31(3):14

Graham, David, 31(6):3

Grant, William, 31(5):31

Grazing Methods: A Viewpoint, 31(5):5

Green, Benedict T., 31(1):5, 31(1):22, 31(1):28

Gunderson-Izurieta, Sharlyn, 31(3):36

$\mathrm{H}$

Hall, Jeffrey O., 31(1):5

Harmon, Dan N., 31(3):30

Havstad, K. M., 31(2):36, 31(5):26, 31(5):39

Hayenga, Wayne A., 31(2):14

Hidinger, Lori, 31(6):1

Highlights, Rangeland Ecology \& Management, 31(1):57, 31(2):45, 31(3):49, 31(4):24, 31(5):48, 31(6):33

Holechek, Jerry L., 31(6):20

I

Identifying Plant Poisoning in Livestock, 31(1):5

Improving Field-Based Experimental Research to Compliment Contemporary Management, 31(5):26

Introduction to the USDAAgricultural Research Service Poisonous Plant Research Laboratory Special Rangelands Issue, 31(1):3

Invasive Weeds on Range and Farmlands-Problems, Causes, and Solutions (An interview with Richard Mack), 31(4):10

J

Jonovic, Donald J., 31(2):8

Joshi, Ankush, 31(2):31

K

Kirby, Donald, 31(6):9

Klinefelter, Danny, 31(2):19 
Kothmann, Mort, 31(5):3, 31(5):5, 31(5):31, 31(5):37

Krabbenhoft, Kelly, 31(6):9, 31(6):16

Krausman, Paul R., 31(5):15

Kulpa, Sarah, 31(2):26

L

Larkspur Poison Weed: 100 Years of

Delphinium Research, 31(1):22

Lee, Stephen T., 31(1):10, 31(1):38, 31(1):45

Leger, Elizabeth, 31(3):14

Lisonbee, Larry, 31(1):45

Listening to the Land, 31(1):52, 31(2):40, 31(3):44, 31(4):19, 31(5):43, 31(6):28

Livestock Grazing, Wildlife Habitat, and Rangeland Values, 31(5):15

Livestock Poisoning With Pyrrolizidine-Alkaloid-Containing Plants (Senecio, Crotalaria, Cynoglossum, Amsinckia,

Heliotropium, and Echium spp.), 31(1):35

Locoweed Poisoning in Livestock, 31(1):16

Longland, William S., 31(2):26

Lyman, Tiffanny, 31(1):45

\section{M}

Management Transitions: Handing

Over the Reins, 31(2):19

Markin, George P., 31(3):36

McAdoo, Kent, 31(3):30

McCann, Brent, 31(2):19

McCuin, Gary, 31(3):30

McDaniel, Kirk, 31(6):3

McGuire, Susan R., 31(1):50, 31(3):41, 31(5):41

Motteram, Ernie, 31(1):10

N

Naugle, David E., 31(5):15

News Reports, 31(6):26

Nilson, David, 31(6):9
Northrup, Rick, 31(5):15

Nowak, Bob, 31(3):21

0

Olson, Denise L., 31(2):31

Olsson, Aaryn, 31(3):6

Ostendorf, Joel, 31(6):16

Owens, Jake, 31(1):45

P

Painter and Range Rider, 31(4):18

Panter, Kip E., 31(1):3, 31(1):5, 31(1):10, 31(1):28, 31(1):38, 31(6):3

Pfister, James A. (Jim), 31(1):3, 31(1):22, 31(1):28, 31(6):3

Platt, Tom E., 31(1):10

Positioning Your Ranch for Business

Succession, 31(2):4

Provenza, Frederick D., 31(1):45

$\mathbf{R}$

Radakovich, J. D., 31(2):4

Ralphs, Michael H., 31(1):10, 31(1):16, 31(1):38, 31(6):3

Range Livestock Production, Food, and the Future: A Perspective, 31(6):20

Reedy, Nan, 31(3):36

Revisiting Leafy Spurge Biocontrol:

A Case Study, 31(2):31

Rogstad, Alix, 31(3):6

Rotational Grazing and the

Profession and Practice of

Rangeland Management, 31(5):3

Rotational Grazing on Rangelands:

Synthesis and Recommendations, 31(5):37

S

Selected Common Poisonous Plants of the United States' Rangelands, 31(1):38

Shane, Ryan S., 31(3):30

Solutions to Locoweed Poisoning in

New Mexico and the Western

United States, 31(6):3
Southern Idaho Student

"Bug Crews", 31(3):36

SRM Center for Professional

Education and Development:

Wildfires and Invasive Plants in

American Deserts, 31(3):2

Stegelmeier, Bryan L., 31(1):5, 31(1):16, 31(1):35, 31(6):3

Svejcar, Tony, 31(5):26

Swanson, Sherman, 31(3):2, 31(3):25

Swartz, Maryke, 31(2):26

$\mathrm{T}$

Tanaka, John A., 31(3):2

Teague, Richard, 31(5):31

The Effect of Poisonous Range

Plants on Abortions in Livestock, 31(1):28

Thompson, David, 31(6):3

Thorpe, Jim, 31(5):11

V

Value of Plant Diversity for Diet Mixing and Sequencing in

Herbivores, 31(1):45

Viewpoint: New Approaches and Protocols for Grazing Management Research, 31(5):31

Villalba, Juan J., 31(1):45

W

Wallace, Mark C., 31(5):15

Welch, Kevin D., 31(1):5, 31(1):16, 31(1):28, 31(1):45, 31(6):3

Who's Eating the Flowers of a Rare Western Nevada Range Plant?, 31(2):26

Wiedmeier, Randy W., 31(1):45

Wildfire Rehabilitation and

Restoration: Triage in the Pursuit of Resilience, 31(3):30

Wilson, Conner, 31(2):14

Wittman, Dick, 31(2):4

Working Landscapes: Providing for the Future, 31(4):2

Wright, Jeffrey D., 31(5):15 